\title{
Improving Career Planning using Website-Based Career Information Service
}

\author{
Hotma Rosalin ${ }^{1}$, Sunawan, Edy Purwanto \\ Universitas Negeri Semarang, Indonesia \\ هotmarosalin@yahoo.co.id ${ }^{1}$
}

\section{Article Information: \\ Received March 29, 2018 \\ Revised April 17, 2018 \\ Accepted July 10, 2018}

Keywords: career planning, website-based, career information service.

\begin{abstract}
Career is a life long process. This study aims to improve the career planning of senior high school students in Tarakan City through information career services assistance through the website.The experimental design used in this research is quasi-experiment in the form of one group pretest-post design. The career planning scale consists of 45 items with 5 falling itemsand 0.875 alpha coefficient. This study involved 35 students as an experimental group selected by purposive sampling.The result of this research is career information service the website-assistedeffectively improve the career planning of high school students in Tarakan City $(10,094$, $\mathrm{p}<0.01)$.
\end{abstract}

\section{INTRODUCTION}

Careers are a lifelong process, chosen and determined to go through a process that not only takes into account the personal strengths and weaknesses of individuals but focuses on the extrinsic aspects of satisfaction in choosing jobs such as money, status and working conditions(Nathan \& Hill, 2005). Ginzberg's development theory (Bruder, 2010) mentions that senior high school students are at a tentative stage where students should be able to think or plan their careers based on their interests and values or potentials. Career planning is one of the most important aspects of individual career development. Skills in making decisions are the main goals in career planning that every individual should take.

Experience in the field shows that there are still many students who are confused about choosing majors or study programs that will be entered especially for senior high school students. Some students make career plans based solely on their wishes and desires without considering their abilities, even where students submit career options to peers or others. Research conducted Budiamin (2002)in Bandung regency explains that as many as $90 \%$ of learners said still confused in choosing a career in the future and $70 \%$ of learners declare future plans depending on the parents(Abavian, 2013). Seeing that fact, to determining the right career and in accordance with the talents, interests, intelligence levels, and values of life owned by students need to be planned first. Student career planning is not just a job he holds, but a job that really suits his potential. Some students plan their careers unrealistically. They make career plans based solely on their willingness and desire without considering their abilities.

The phenomenon of low career planning experienced by students is one of the impacts of less optimal implementation of guidance and counseling services. Responding to the phenomenon there needs to be cooperation between counselors with all stakeholders.

$\begin{array}{ll}\text { How to cite : } & \text { Rosalin, H., Sunawan, \& Purwanto, E. (2018). Improving Career Planning using Website-Based Career } \\ & \text { Information Service. Islamic Guidance and Counseling Journal, 1(2), 62-68. } \\ & \text { https://doi.org/10.25217/igcj.v1i2.239 } \\ \text { E-ISSN: } & \text { 2614-1566 } \\ \text { Published by: } & \text { Institut Agama Islam Ma'arif NU (IAIMNU) Metro Lampung } \\ \text { Available online: } & \text { https://journal.iaimnumetrolampung.ac.id/index.php/igcj }\end{array}$


Counselors should work together to help students with low career planning. It is important for students in career planning before students finally make career decisions. One form of service that can be provided is a career information service to improve career planning.

In the information era now, the internet is the most popular media in social relations, education, work, science, and much more, it is unfortunate when the media is left alone, while in fact, this is the most widely used media, has been proven from the demand for sim card access prepaid continues to increase, home network demand, and the availability of wifi networks in every place that is more comprehensive. This is a problem and also a very good potential, will be a problem when users have no protection and services that lead to positive things then it can make the students as users fall into the negative and misleading things, but this is the most potential medium in providing various services and can be used in the provision of information career services.

Of the various information technology products, website is the most interesting, creative, and innovative product for students because, in a website, students will get a variety of information complete with a creative and innovative display, so that will increase the interest of learners, and media of this website will be very suitable applied to increase student interest. Research by Abiyose, Blessing, \& Ganiyu (2015) suggests that students' high interest in the use of websites because students can independently online, can obtain various information in both educational and career information. Students can access the various information provided by guidance and counseling teachers through the website. This is in line with the statements by Van Horn \& Myrick (2001) in the scope of computer technology school counseling services such as websites can be used to obtain various information relating to various universities, professions, to manage counseling interventions, to build relationships from various cities and countries, and to receive education and monitoring. Therefore, to help learners increase interest, school counselors are required to be able to create creative and innovative career information services with the help of websites.

Empirically, career information services are effective in improving career planning but no research has been found that describes career based information services of a particular approach to improve student career planning. In addition, giving changes to students in helping the mindset of students to the views in the career direction of career choices that enter the world of education and the world of work (Klaus, 2010; Mabula, 2012; Ummah, 2013; Witko, Bernes, Magnusson, \& Bardick, 2009).

Implementation of career information services involving website assistance allows career information services to be carried out easily and indefinitely because it can be implemented anywhere. Because with the help of the website, will become more innovative in the implementation of career information services to run more optimal. The website assisted career information service emphasizes on improving student career planning so that students know of their chosen careers and know the career options that match their talents, interests and intelligence levels. This is the foundation for researchers to conduct career-assisted website information services to improve student career planning.

\section{METHOD}

This research is a type of quantitative research that directly test the influence of another variable and test the hypothesis about the different level of career planning before and after given treatment information service assisted care website. The experimental design used in this research is quasi-experiment in the form of one group pretest-post design. The study participants consisted of 35 students of class XII in SMA Negeri 3 Kota Tarakan. Participants selected by purposive sampling. The experimental design used is one group pretest-posttest design which can be described as follows: 


\begin{tabular}{cccc}
\hline Group & Pre Test & Treatment & Post Test \\
\hline Experiment & $\mathrm{O}_{1}$ & $\mathrm{X}$ & $\mathrm{O}_{2}$ \\
\hline
\end{tabular}
Information:

Table 1. The experimental design used is one group pretest-posttest design

$\mathrm{O}_{1} \quad$ : Level of career planning on the pre-test.

$\mathrm{O}_{2} \quad$ : The level of career planning after being given the treatment of career-assisted website information services.

$\mathrm{X} \quad$ : Treatment is given for 8 days (through $1 \mathrm{x}$ reading sessions and through the question and answer room (comments service) available on the website

Data collection technique in this research is to use career planning scale. The career planning scale consists of 45 items with the falling item 5. The result of the instrument test, the career planning scale item is valid with the correlation index $\geq 0.3$ with the alpha coefficient of 0.875 . The data obtained were then analyzed using a t-test.

\section{RESULTS AND DISCUSSION}

The condition of career planning of SMA Negeri 3 Kota Tarakan students in the experimental group in the high category were 2 students, in the medium category were 14 students while for the low category were 19 students. After getting career information services assisted by the website, career career planning condition increased to high category as many as 26 students and medium category as many as 9 students.

\begin{tabular}{|c|c|c|}
\hline \multicolumn{2}{|c|}{ Measurement } & Experiment $(\mathrm{N}=35)$ \\
\hline \multirow[t]{2}{*}{ Pretest } & $\mathrm{M}$ & 95,69 \\
\hline & SD & 16,28 \\
\hline \multirow[t]{2}{*}{ Posttest } & M & 124,94 \\
\hline & SD & 10,020 \\
\hline$t^{1}$ & & 10,094 \\
\hline $\mathrm{p}^{1}$ & & $.000(<0,01)$ \\
\hline
\end{tabular}

Table 2. The result of impact analysis

The data were then analyzed using a t-test. The results show that career information services assisted by the website can improve student career planning significantly. Of the overall career planning scores of students have increased. From pretest score with a mean of 95,69 and posttest score equal to 124,94. An increased mean score of 29.2 points or $30.6 \%$ affected by treatment career information services assisted by the website.

Based on the analysis of hypothesis data with $t$ value $\leq$ ttable $(1-\alpha)$, the difference test shows that the number of $\mathrm{t}$ value $\leq \mathrm{t}$ table $(1-\alpha)$ with tcount: $10,094, \mathrm{p}<0.01$. This proves that the value of $t$ arithmetic is greater than $t$ table and based on the value of significance that is greater or equal to 0.05 so it can be concluded that career information services can improve student career planning.

This study is intended to test the effectiveness of career information services assisted by the website to improve student career planning. The results of this study indicate that career information services assisted by website effective to improve student career planning. This is evidenced through the effectiveness test results that prove that there is an increase in the pretest score (preliminary assessment) and post-test score (final evaluation).

This result is consistent with the study of Abiyose et al. (2015) that career information services assisted by websites provided to junior high school students assist students in searching for a variety of advanced educational information that contributes to their career planning. This study presents a career quiz along with its interpretation that will direct junior 
high school students to career planning. Compared to the findings ofAbiyose et al. (2015), then this research performs effectiveness test career information services assisted by the website to improve career planning of high school students in Tarakan City. Website bkkarirtarakan.com does not present a career quiz but presents various information about the college, provides a worksheet and a specialized career information service for users who want to ask questions.

Website quality assessment is divided into four, among others, usability quality, information quality, interaction quality and overall. Based on the results of product quality assessment by students indicate that the product on the category is very good. The quality of the website in terms of quality of use, display (website pages) is quite interesting by presenting a picture of one of the professions of "business management" so that users understand that the theme of this website related to career. The website can be viewed in a single screen display so as to facilitate the user to see the entire look of the website at once, the design color of the display is very clear by using the majority of light blue color. The blue color is the color associated with positive emotional effects such as relaxation, pleasant feeling, and increased attraction to buy a product (Nordeborn, 2013).

In addition, the download speed of the display (website page) is quite fast, the picture resolution is quite balanced, the graphic design is tailored to the type of website so it looks attractive, and the image according to the type of website. Some materials are given pictures and videos so that the website does not look monotonous. These results indicate that students respond well to the look of the website www.bkkarirtarakan.com and make students interested in using the website to obtain information related to career planning. Thus the main feature on the website that gives a good impression of the students on the website in the fulfillment of various information. The results of this study supported by the theory proposed by Flavián, Guinalíu, \& Gurrea (2006) argue that appearance (website view) must be considered to achieve the success of a website. The first impression of the look of a website determines the evaluation of website users that will affect perception and behavior. In particular, the aesthetic aspect can affect the level of satisfaction on a website. In addition, the aesthetic look of a website from a website shows the credibility of a website. This is similar to the study by Flavián et al. (2006) and Chen, Wigand, \& Nilan (1999)suggests that a good or attractive look or design can evoke feelings of joy and positivity so that the level of usability of the perceived website can lead to satisfaction, trustworthiness and high fidelity to the website.

Then the assessment on the quality of information, the content on the website www.bkkarirtarakan.com very clear, the information relevant to the needs of students ie information about career planning, every material updated and updated in particular include the schedule of implementation of various state universities, the material sourced from articles and various reliable references, having the right information, presenting complete information on job prospects in various faculties and the size of the image provided is quite appropriate. Content on the website is developed based on aspects of career planning so that it becomes a guide for students in planning their career.

Good content of a website is content that can meet the needs of online users provided by the website and should be well organized. In this case, the needs of students is a variety of information related to career planning. The quality of information on the website affects in decision making or other tasks on the users of the website. The better the quality of the information, the more appropriate the decisions taken (Istianingsih \& Utami, 2009). Glassberg, Grover, \& Teng (2006) argue that the quality of information affects affective components (user emotions, feelings of satisfaction or dissatisfaction, mood, and user evaluation like likes or dislikes). This is reinforced by the results of the assessment of UCA (understanding, comfort, action) in which students stated that feeling satisfied, happy, feel helpful and interested in the website bkkarirtarakan.com because students obtain various 
information colleges. This is relevant to this research, the quality of bkkarirtarakan.com website information proved to be in the very good category so as to help students improve their career planning.

In addition, the assessment of the quality of interaction is in the category of good because the website bkkarirtarakan.com menu available "special career information services" to include e-mail and contact numbers for students to submit questions or comments as a discussion forum so as to create more communities specific through a special career information service. The quality of interaction is considered important for a website as it facilitates two-way communication with its users (Fan, Yul Lee, \& In Kim, 2013). In this case, the discussion forum through the "special career information service" menu facilitates students independently through online to deliver all their questions.

Then, bkkarirtarakan.com website presents a "worksheet" menu. The worksheet is done by students via online then the result will be sent via email to admin email. The worksheet is provided for students as a form of students' self-assessment of their career planning. Selfassessment is important for students as a basic consideration before they plan and even make decisions for their careers. Permadi (2016)suggests that self-assessment is the foundation for all career planning, the individual must know what is desired, the interests, the characteristics of ability and personality itself. Self-assessment becomes central and fundamental in one's career planning.

Career information services provided by guidance and counseling teachers to students can assist teachers' counseling and in providing information related to their career planning (Abiyose et al., 2015). Websites are used to support the performance of counselors and as a medium to interact with students. Websites can be utilized as a media for schools that do not have an allocation of guidance and counseling hours and the capacity of guidance and counseling teachers who are unable to serve the needs of students so that the implementation of career information services can run optimally. From this research and conducted by the researcher, the website gives ease to guidance and counseling teacher in giving various important information related to career and can interact with the student without having to meet face to face with still paying attention to the principles and code of ethics in guidance and counseling.

Career information service assisted by the website to improve the career planning of students consists of 1 reading session and for the next student to go online with a flexible time to read the various information available on the website bkkarirtarakan.com according to his needs. But for the purpose of service to students, researchers provide a special time to interact directly with the counselor. In this study, the online schedule for the Q \& A session is conducted from $6 \mathrm{pm}$ to $9 \mathrm{pm}$.

Career information service assisted by websites to improve career planning have implications for guidance and counseling teachers. In this case counseling and guidance teachers should be able to fully support the career planning of students in accordance with the needs of students especially in the field of career, this is supported by opinions in research Witko et al. (2009) states that the high career needs of students in grade XII related to the information needs of colleges and job prospects have implications for the role of counselors in providing assistance services in the form of providing career information services in helping to improve student career planning. Students need counselor information, advice, and direction in assisting them in career planning. The results of this study also aligned with previous research that students are prepared to assist career decisions thus re-emphasizing the importance of career planning (Hiebert, Collins, \& Robinson, 2001). Thus, teacher guidance and counseling in schools are very relevant in implementing career information services assisted by websites to improve career planning of high school students as it proved its effectiveness through a limited trial. 
Career information service assisted by website is expected to fully support the improvement of career planning students in the city of Tarakan and is expected to further researchers career information service assisted by website model can be generalized to all high school students in Indonesia with various levels and implementation of career-assisted information service website model not only through online reading sessions, but career information service assisted by website model can be done by class or by using blended learning method.

\section{CONCLUSION}

This research was conducted to improve career planning of senior high school students of XII SMA in Kota Tarakan through career information service assisted by the website. The results of this study indicate that career information service assisted by websites can improve the career planning of students significantly. This is based on the acquisition of pre-test and post-test scores on the career planning scale after following career information service assisted by the website.

More important for guidance and counseling teachers or school counselors to understand the basic concepts of career information services and media guidance and counseling in the form of websites, because the implementation of career information services assisted by websites collaborates between career information services and media guidance and counseling in the form of websites. In addition, it is expected for further researchers to test career information services assisted by websites against other variables and with different samples

\section{REFERENCES}

Abavian, M. (2013). Program Bimbingan Karir untuk Meningkatkan Kemampuan Perencanaan Karir Peserta Didik. Bandung: UPI.

Abiyose, Blessing, \& Ganiyu. (2015). A Web-Based Career Guidance Information System for Pre-Tertiary Institution Students in Nigeria. Journal of Engineering and Technology, 1(3).

Bruder, M. B. (2010). Early childhood intervention: A promise to children and families for their future. Exceptional Children, 76(3), 339-355.

Budiamin, A. (2002). Manajemen Layanan Bimbingan Karir pada SMA Negeri di Kabupaten Bandung. Jurnal Psikologi Pendidikan Dan Bimbingan, 2(2), 259-266.

Chen, H., Wigand, R. T., \& Nilan, M. S. (1999). Optimal experience of web activities. Computers in Human Behavior, 15(5), 585-608.

Fan, Q., Yul Lee, J., \& In Kim, J. (2013). The impact of website quality on flow-related online shopping behaviors in C2C e-marketplaces: A cross-national study. Managing Service Quality: An International Journal, 23(5), 364-387.

Flavián, C., Guinalíu, M., \& Gurrea, R. (2006). The role played by perceived usability, satisfaction and consumer trust on website loyalty. Information \& Management, 43(1), $1-14$.

Glassberg, B. C., Grover, V., \& Teng, J. T. (2006). Information systems research with an attitude. ACM SIGMIS Database: The DATABASE for Advances in Information Systems, 37(2-3), 76-85.

Hiebert, B., Collins, S., \& Robinson, J. (2001). Needs assessment for program planning and program development: A brief review. The Alberta Counsellor, 26(1), 11-18. 
Istianingsih, I., \& Utami, W. (2009). Pengaruh Kepuasan Pengguna Sistem Informasi Terhadap Kinerja Individu. In Simposium Nasional Akutansi XII (pp. 1-70).

Klaus, J. N. (2010). High School Career Education: Student's Perceptions of The Life Planning Course. Journal High School University, 2(1).

Mabula, N. (2012). Career Services Provision to Secondary School Students in Tanzania: Is it a dream or Reality? International Journal of Learning and Development, 2(2), 242-257.

Nathan, R., \& Hill, L. (2005). Career counseling. Sage.

Nordeborn, G. (2013). The Effect of Color on Website Design: Searching for Medical Information Online.

Permadi, N. E. (2016). Masalah-Masalah yang Dihadapi Peserta Didik dalam Perencanaan Karir dan Implikasinya terhadap Pelayanan Bimbingan Karir. Jurnal Penelitian Bimbingan Dan Konseling, 1(2).

Ummah, M. (2013). Penerapan Layanan Informasi Karier untuk Meningkatkan Kemampuan Perencanaan Karier Siswa Kelas XII SMAN I Krembung Sidoarjo. Jurnal BK UNESA, l(1).

Van Horn, S. M., \& Myrick, R. D. (2001). Computer technology and the 21st-century school counselor. Professional School Counseling, 5(2), 124.

Witko, K., Bernes, K. B., Magnusson, K., \& Bardick, A. D. (2009). Senior high school career planning: What students want. The Journal of Educational Enquiry, 6(1). 